\title{
TU/e EmonONEN

\section{Excellent passivation of highly doped p-type Si surfaces by the negative-charge-dielectric Al2O3}

\section{Citation for published version (APA):}

Hoex, B., Schmidt, J., Bock, R., Altermatt, P. P., Sanden, van de, M. C. M., \& Kessels, W. M. M. (2007). Excellent passivation of highly doped p-type Si surfaces by the negative-charge-dielectric Al2O3. Applied Physics Letters, 91(11), [112107]. https://doi.org/10.1063/1.2784168

DOI:

$10.1063 / 1.2784168$

Document status and date:

Published: 01/01/2007

\section{Document Version:}

Publisher's PDF, also known as Version of Record (includes final page, issue and volume numbers)

\section{Please check the document version of this publication:}

- A submitted manuscript is the version of the article upon submission and before peer-review. There can be important differences between the submitted version and the official published version of record. People interested in the research are advised to contact the author for the final version of the publication, or visit the $\mathrm{DOI}$ to the publisher's website.

- The final author version and the galley proof are versions of the publication after peer review.

- The final published version features the final layout of the paper including the volume, issue and page numbers.

Link to publication

\section{General rights}

Copyright and moral rights for the publications made accessible in the public portal are retained by the authors and/or other copyright owners and it is a condition of accessing publications that users recognise and abide by the legal requirements associated with these rights.

- Users may download and print one copy of any publication from the public portal for the purpose of private study or research.

- You may not further distribute the material or use it for any profit-making activity or commercial gain

- You may freely distribute the URL identifying the publication in the public portal.

If the publication is distributed under the terms of Article 25fa of the Dutch Copyright Act, indicated by the "Taverne" license above, please follow below link for the End User Agreement:

www.tue.nl/taverne

Take down policy

If you believe that this document breaches copyright please contact us at:

openaccess@tue.nl

providing details and we will investigate your claim. 


\title{
Excellent passivation of highly doped $p$-type Si surfaces by the negative-charge-dielectric $\mathrm{Al}_{2} \mathrm{O}_{3}$
}

\author{
B. Hoex ${ }^{\text {a) }}$ \\ Department of Applied Physics, Eindhoven University of Technology, P.O. Box 513, 5600 MB Eindhoven, \\ The Netherlands \\ J. Schmidt and R. Bock \\ Institute for Solar Energy Research Hameln (ISFH), Am Ohrberg 1, D-31860 Emmerthal, Germany \\ P. P. Altermatt \\ Department of Solar Energy, Institute of Solid-State Physics, University of Hannover, Appelstrasse 2, \\ 30167 Hannover, Germany \\ M. C. M. van de Sanden and W. M. M. Kessels ${ }^{\text {b) }}$ \\ Department of Applied Physics, Eindhoven University of Technology, P.O. Box 513, 5600 MB Eindhoven, \\ The Netherlands
}

(Received 6 July 2007; accepted 21 August 2007; published online 11 September 2007)

\begin{abstract}
From lifetime measurements, including a direct experimental comparison with thermal $\mathrm{SiO}_{2}$, $a-\mathrm{Si}: \mathrm{H}$, and as-deposited $a-\mathrm{SiN}_{x}: \mathrm{H}$, it is demonstrated that $\mathrm{Al}_{2} \mathrm{O}_{3}$ provides an excellent level of surface passivation on highly $\mathrm{B}$-doped $c$-Si with doping concentrations around $10^{19} \mathrm{~cm}^{-3}$. The $\mathrm{Al}_{2} \mathrm{O}_{3}$ films, synthesized by plasma-assisted atomic layer deposition and with a high fixed negative charge density, limit the emitter saturation current density of B-diffused $p^{+}$-emitters to $\sim 10$ and $\sim 30 \mathrm{fA} / \mathrm{cm}^{2}$ on $>100$ and $54 \Omega / \mathrm{sq}$ sheet resistance $p^{+}$-emitters, respectively. These results demonstrate that highly doped $p$-type Si surfaces can be passivated as effectively as highly doped $n$-type surfaces. () 2007 American Institute of Physics. [DOI: 10.1063/1.2784168]
\end{abstract}

Research within the crystalline silicon $(c-\mathrm{Si})$ photovoltaic community is driven by the necessity to decrease the costs per watt peak. As a consequence, the thickness of $c-\mathrm{Si}$ solar cells is reduced and alternative $c$-Si material and production processes are investigated. Presently, most Si solar cells are fabricated from $p$-type $c$-Si base material. However, the relative insensitivity of $n$-type $c$-Si to various impurities and defects could well result in a switch in the future to predominantly $n$-type base material. ${ }^{1}$ The success of these developments will depend, among others, on the level of surface passivation that can be obtained on the surfaces of interest. Especially the passivation of highly doped $p$-type surfaces is of key interest for diffused emitter cells based on $n$-type silicon.

The passivation of highly B-doped $p$-type $c$-Si (for example, a $p^{+}$-emitter on a $n$-type $\mathrm{Si}$ wafer) is still trailing behind the results obtained on highly doped $n$-type $c$-Si. ${ }^{2,3}$ This gap in performance can, at least partly, be explained by the presence of positive built-in charges in the commonly used passivation films such as thermal $\mathrm{SiO}_{2}$ and as-deposited $a-\mathrm{SiN}_{x}: \mathrm{H}^{2}{ }^{2}$ Recently, Chen et al., however, demonstrated that highly B-doped $p$-type $c$-Si can be effectively passivated by silicon rich $a$-SiN $\mathrm{S}_{x}: \mathrm{H}$ after prolonged annealing (up to $4 \mathrm{~h}$ ) yielding an at least equal performance to as-grown thermal $\mathrm{SiO}_{2}$ for sheet resistances $>130 \Omega /$ sq. ${ }^{4}$ Furthermore, it was shown that $a-\mathrm{Si}: \mathrm{H}$ can yield a surface passivation of $p^{+}$-emitters comparable to forming gas annealed thermal oxide $^{2}$ whereas the performance of $a-\mathrm{SiC}_{x}: \mathrm{H}$ remained significantly poorer. ${ }^{5}$

An appealing approach is to passivate highly doped

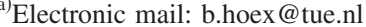

b) Electronic mail: w.m.m.kessels@tue.nl
}

$p$-type $c$-Si by a dielectric containing a fixed negative charge density. In this way, the minority carrier (electron) concentration is effectively reduced at the highly defective surface and consequently the recombination rate is reduced. It is well known that $\mathrm{Al}_{2} \mathrm{O}_{3}$ can contain a high density of built-in negative charges (up to $\sim 10^{13}$ elementary charges $/ \mathrm{cm}^{2}$ ) and $\mathrm{Al}_{2} \mathrm{O}_{3}$ has recently been shown to provide a state-of-the-art level of surface passivation on moderately doped $p$ - and $n$-type $c$-Si. ${ }^{6,7}$ In this letter, we show that $\mathrm{Al}_{2} \mathrm{O}_{3}$ synthesized by plasma-assisted atomic layer deposition (ALD) provides an excellent level of surface passivation on B doped $p^{+}$-type emitters with surface concentrations ranging from 5 $\times 10^{18}$ to $3 \times 10^{19} \mathrm{~cm}^{-3}$. From a direct experimental comparison, it is established that $\mathrm{Al}_{2} \mathrm{O}_{3}$ yields a higher level of surface passivation than forming gas annealed thermal $\mathrm{SiO}_{2}$, $a-\mathrm{Si}: \mathrm{H}$, and as-deposited $a-\mathrm{SiN}_{x}: \mathrm{H}$ applied on the same samples. Moreover, it is demonstrated that highly B-doped $p$-type $c$-Si surfaces can as effectively be passivated as highly doped $n$-type $c$-Si surfaces.

The $p^{+} / n / p^{+}$structures used in this study were prepared at the Australian National University by exposing $\langle 100\rangle$ shiny etched $n$-type $c$-Si (90 and $20 \Omega \mathrm{cm}$ ) with a thickness of $\sim 260 \mu \mathrm{m}$ to $\mathrm{BBr}_{3}$ at $T=895-1010{ }^{\circ} \mathrm{C}$. ${ }^{8}$ After stripping the $\mathrm{B}$ containing glass, $\mathrm{B}$ diffusion was driven by thermal oxidation at $1050{ }^{\circ} \mathrm{C}^{8}$ The sheet resistance of the samples was determined by four-point probe measurements and the doping profile, shown in Fig. 1, was determined by both electrochemical capacitance-voltage (ECV) profiling and secondary ion mass spectrometry (SIMS). The level of surface passivation of thermal $\mathrm{SiO}_{2}, a-\mathrm{SiN}_{x}: \mathrm{H}$ and $a-\mathrm{Si}: \mathrm{H}$ on these $p^{+}$-emitter samples was already reported in a previous study. ${ }^{2,8}$ Before deposition a possibly remaining film from previous experiments was stripped off and the samples received a conventional RCA cleaning with a final dip in di- 


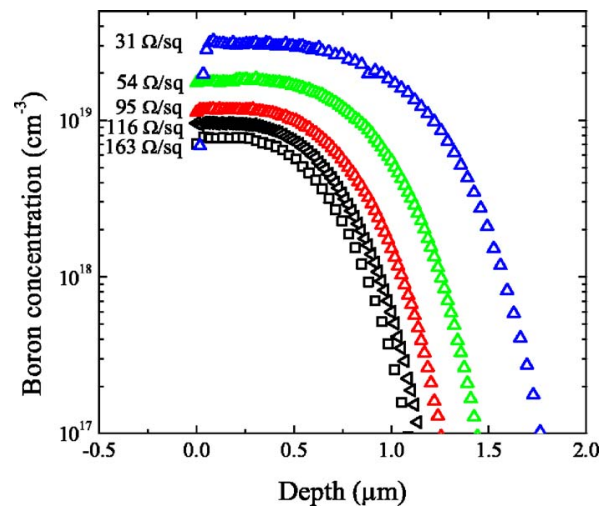

FIG. 1. (Color online) B-doping profiles of the $p^{+} / n / p^{+}$samples with various sheet resistances as determined by ECV profiling and experimentally verified by SIMS measurements (54 and $95 \Omega / \mathrm{sq}$ ).

luted $\mathrm{HF}(1 \%) . \mathrm{Al}_{2} \mathrm{O}_{3}$ films were deposited on both sides of the samples by alternating $\mathrm{Al}\left(\mathrm{CH}_{3}\right)_{3}$ dosing and $\mathrm{O}_{2}$ plasma exposure in a remote plasma ALD reactor (Oxford Instruments FlexAL $\left.{ }^{\mathrm{TM}}\right)$ at a substrate temperature of $200^{\circ} \mathrm{C}^{.9} 255$ ALD cycles of $4 \mathrm{~s}$ resulted in $30 \mathrm{~nm}$ thick $\mathrm{Al}_{2} \mathrm{O}_{3}$ as determined by in situ spectroscopic ellipsometry. Subsequently, the samples received a $30 \mathrm{~min}$ annealing at $425{ }^{\circ} \mathrm{C}$ in $\mathrm{N}_{2} .{ }^{7}$ The passivation quality of the films was quantified by the emitter saturation current density $J_{0 e}$ of the $p^{+}$-emitters. The emitter saturation current density $J_{0 e}$ was determined from contactless photoconductance decay measurements in both the quasi-steady-state and transient mode (Sinton WCT-100) ${ }^{10}$ from the relation proposed by Kane and Swanson ${ }^{11}$

$$
\frac{1}{\tau_{\text {eff }}}-\frac{1}{\tau_{\text {Auger }}}=\frac{1}{\tau_{\mathrm{SRH}}}+2 \frac{J_{0 e}\left(N_{d}+\Delta n\right)}{q n_{i}^{2} W},
$$

where $\tau_{\text {eff }}$ is the measured effective excess carrier lifetime, $\tau_{\text {Auger }}$ the intrinsic Auger lifetime, ${ }^{12} \tau_{\mathrm{SRH}}$ the defect-related bulk lifetime, $N_{d}$ the base doping level, $n_{i}$ the intrinsic carrier concentration of $c-\mathrm{Si}^{1}{ }^{13} q$ the elementary charge, $\Delta n$ the excess carrier density, and $W$ the sample thickness.

In Fig. 2, the Auger-corrected inverse effective lifetimes are shown for samples with various sheet resistances passivated by $30 \mathrm{~nm} \mathrm{Al}_{2} \mathrm{O}_{3}$ films. The curves do not show a

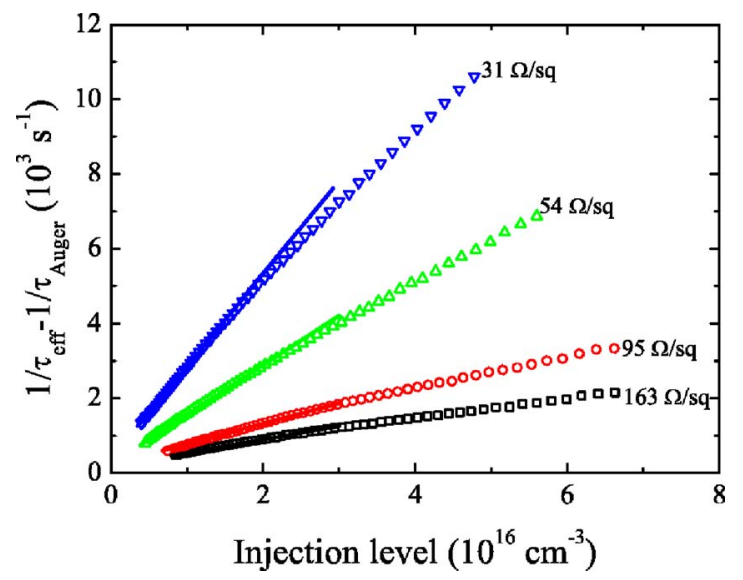

FIG. 2. (Color online) Measured Auger corrected inverse effective lifetime as a function of the injection level for $c$-Si samples with double sided B-doped $p^{+}$-emitter and various sheet resistances passivated on both sides by a $30 \mathrm{~nm} \mathrm{Al} \mathrm{O}_{3}$ film. The emitter saturation current density is extracted

from the linear fit up to $2 \times 10^{16} \mathrm{~cm}^{-3}$ by means of Eq. (1). and the physical models established in Refs. 2 and 3 and the
Downloaded 11 Feb 2008 to 131.155.109.134. Redistribution subject to AlP license or copyright; see http://apl.aip.org/apl/copyright.jsp

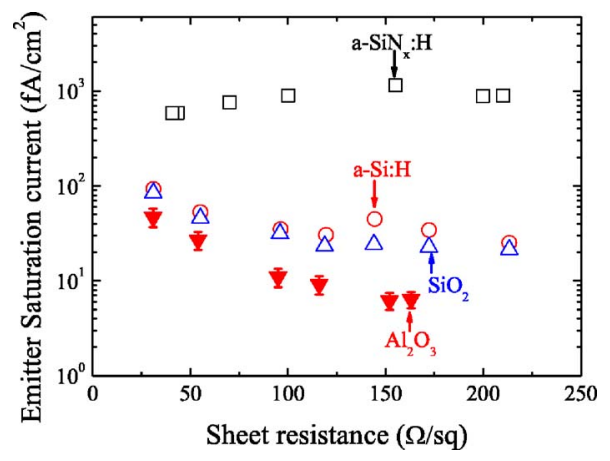

FIG. 3. (Color online) Measured emitter saturation current density $J_{0 e}$ as a function of the sheet resistance for B-doped $p^{+}$-emitter samples passivated by $\mathrm{Al}_{2} \mathrm{O}_{3}$, as-deposited $a-\mathrm{SiN}_{x}: \mathrm{H}, a-\mathrm{Si}: \mathrm{H}$, and forming gas annealed thermal $\mathrm{SiO}_{2}$.

strong nonlinear behavior such as in the case of $a-\mathrm{SiN}_{x}: \mathrm{H}^{8}$ Consequently Eq. (1) can be used to extract $J_{0 e}$ and no alternative quantification such as implied open-circuit voltage has to be used in this case. ${ }^{14}$ Nevertheless a small nonlinearity is still observed, possibly explained by minor experimental uncertainties or uncertainty in the empirically determined Auger lifetime at high injection level. ${ }^{12}$ Therefore, $J_{0 e}$ is determined for a moderate injection level up to $2 \times 10^{16} \mathrm{~cm}^{-3}$ where Auger recombination does not dominate. Similar to the results obtained on lightly doped $n$ - and $p$-type $c$-Si, ${ }^{7}$ the level of surface passivation by $\mathrm{Al}_{2} \mathrm{O}_{3}$ is dramatically affected by the postdeposition annealing. The emitter saturation current for the $163 \Omega / \mathrm{sq}$ sample coated with an asdeposited $\mathrm{Al}_{2} \mathrm{O}_{3}$ film (not shown) is in the order of $\sim 1.2$ $\times 10^{3} \mathrm{fA} / \mathrm{cm}^{2}$, which is comparable to a nonpassivated sample, and is reduced to below $10 \mathrm{fA} / \mathrm{cm}^{2}$ after a $30 \mathrm{~min}$ annealing at $425{ }^{\circ} \mathrm{C}$ in $\mathrm{N}_{2}$. This dramatic improvement in surface passivation is related to changes at the $c-\mathrm{Si} / \mathrm{Al}_{2} \mathrm{O}_{3}$ interface affecting both the amount of built-in negative charge and the interface defect density as will be reported in a separate study.

In Fig. 3, the extracted $J_{0 e}$ values are shown as a function of the emitter sheet resistance of $p^{+}$-emitters passivated by $\mathrm{Al}_{2} \mathrm{O}_{3}$ and are compared to earlier published results for thermal $\mathrm{SiO}_{2}, a-\mathrm{Si}: \mathrm{H}$ and $a-\mathrm{SiN}_{x}: \mathrm{H}^{2,8}$ The $p^{+}$-emitter samples with $\mathrm{SiO}_{2}$ were forming gas annealed and those with $a$-SiN $\mathrm{N}_{x}: \mathrm{H}$ were as deposited. Clearly, the $J_{0 e}$ values obtained for $\mathrm{Al}_{2} \mathrm{O}_{3}$ are significantly lower for the complete sheet resistance range tested; $J_{0 e}$ values below $10 \mathrm{fA} / \mathrm{cm}^{2}$ are obtained for a sheet resistance $>100 \Omega / \mathrm{sq}$ and $J_{0 e}$ is only $\sim 50 \mathrm{fA} / \mathrm{cm}^{2}$ for a $31 \Omega / \mathrm{sq}$ emitter. The emitter saturation currents on $p^{+}$-emitters are even lower than obtained on highest-quality $n^{+}$-emitters with a comparable sheet resistance passivated with aluminum annealed thermal $\mathrm{SiO}_{2}$ or as-deposited $a$-SiN ${ }_{x}: \mathrm{H}^{15}$ The emitter saturation current density obtained in this study for a $95 \Omega /$ sq emitter would limit the room temperature open circuit voltage of a solar cell to $747 \mathrm{mV}$ by applying the ideal diode law and assuming a short-circuit current of $40 \mathrm{~mA} / \mathrm{cm}^{2} .{ }^{16}$

The most fundamental property to compare, however, is the surface recombination velocity at the highly doped B surface which strongly depends on the surface doping concentration. The $S_{n 0}$ values were extracted from the experimental $J_{0 e}$ values and dopant profiles by numerical modeling using the device simulation package SENTAURUS (Ref. 17) and the physical models established in Refs. 2 and 3 and the to AIP license or copyright; see http://apl.aip.org/apl/copyright.jsp 


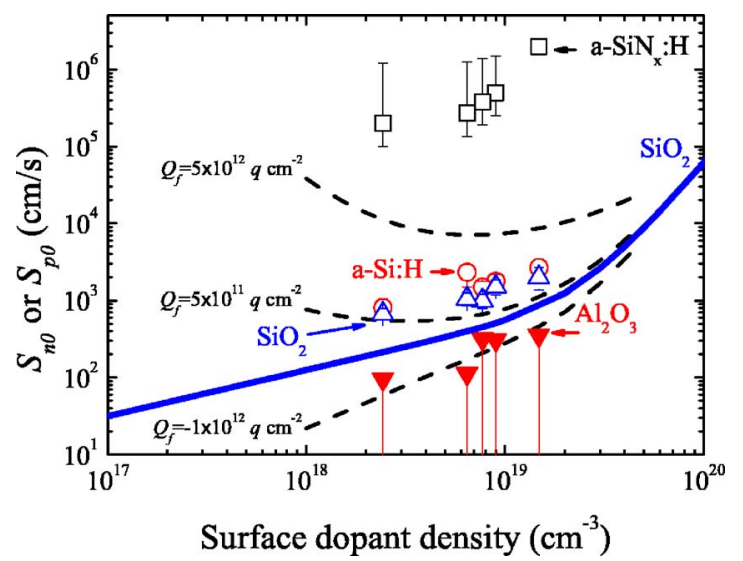

FIG. 4. (Color online) Surface recombination velocity $S_{n 0}$ at the B-doped $p^{+}$-type $c$-Si surface as a function of the surface dopant density as determined by ECV measurements. The $S_{n 0}$ values were deduced by device simulation using the values in Figs. 1 and 3. The solid blue line indicates the empirical relation obtained for $S_{p 0}$ obtained on heavily doped $n$-type surfaces passivated by aluminum annealed thermal $\mathrm{SiO}_{2}$ (see Ref. 3). By assuming $S_{p 0}=S_{n 0}$ this empirical relation is used to simulate the impact of positive and negative built-in charges $Q_{f}$ on $S_{n 0}$ as indicated by the dashed lines.

results are shown in Fig. 4. The experimental errors in both $J_{0 e}$ and the dopant profile and the relative strong Auger recombination in these emitters only allowed extraction of the maximum error bounds for the $\mathrm{Al}_{2} \mathrm{O}_{3}$. For comparison also the $S_{n 0}$ values obtained for thermal $\mathrm{SiO}_{2}, a-\mathrm{Si}: \mathrm{H}$, and $a-\mathrm{SiN}_{x}: \mathrm{H}$ are given as determined on the same sample set. ${ }^{2}$ The solid blue line in Fig. 4 shows the empirically determined limit of the surface recombination velocity $S_{p 0}$ obtained by aluminum annealed thermal $\mathrm{SiO}_{2}$ on highly doped $n^{+}$-emitters. ${ }^{3}$ From Fig. 4 it is evident that the level of surface passivation on highly doped $p$-type $c$-Si provided by thermal $\mathrm{SiO}_{2}, a-\mathrm{Si}: \mathrm{H}$, and $a-\mathrm{SiN}_{x}: \mathrm{H}$ was significantly poorer than what is obtained on highly doped $n$-type $c$-Si. Moreover, the $S_{n 0}$ values obtained by $\mathrm{Al}_{2} \mathrm{O}_{3}$ on the highly doped $p$-type $c$-Si are well below the best values obtained on highly doped $n$-type surfaces which indicates that highly doped $p$-type surfaces can as effectively be passivated as highly doped $n$-type $c$-Si. Figure 4 also illustrates that a negative built-in charge is indeed very beneficial for passivating highly doped $p$-type surfaces compared to the positive built-in charge commonly present in thermal $\mathrm{SiO}_{2}$ and asdeposited $a-\mathrm{SiN}_{x}: \mathrm{H}$. At the same time the excellent results for $\mathrm{B}$ concentrations of $\sim 10^{19} \mathrm{~cm}^{-3}$ indicate that also the $c$-Si/ $\mathrm{Al}_{2} \mathrm{O}_{3}$ interface defect density is sufficiently low and/or that the dominant interface defect has a relatively low electron capture cross section.

In summary, we have demonstrated that $\mathrm{Al}_{2} \mathrm{O}_{3}$ synthesized by plasma-assisted atomic layer deposition shows an excellent level of surface passivation on highly doped $p$-type $c$-Si. Consequently, highly doped $p$-type $c$-Si can as effectively be passivated as highly doped $n$-type $c$-Si allowing maximum freedom in the solar cell design either using $p$-type or $n$-type $c$-Si base material.

The authors acknowledge the experimental work of M. Kerr and A. Cuevas, and thank W. Keuning, M. J. F. van de Sande, J. F. C. Jansen and J. J. A. Zeebregts for their skillful technical assistance. The Netherlands Technology Foundation STW is acknowledged for their financial support. The work of one of the authors (B.H.) is financially supported by OTB Solar. The research of another author (W.K.) has been made possible by a fellowship of the Royal Netherlands Academy of Arts and Sciences (KNAW).

${ }^{1}$ D. Macdonald and L. J. Geerligs, Appl. Phys. Lett. 85, 4061 (2004).

${ }^{2}$ P. P. Altermatt, H. Plagwitz, R. Bock, J. Schmidt, R. Brendel, M. J. Kerr, and A. Cuevas, Proceedings of the 21st EU-PVSEC, Dresden (WIP Renewable Energies, Munich, 2006), p. 647.

${ }^{3}$ P. P. Altermatt, J. O. Schumacher, A. Cuevas, M. J. Kerr, S. W. Glunz, R. R. King, G. Heiser, and A. Schenk, J. Appl. Phys. 92, 3187 (2002).

${ }^{4}$ F. W. Chen, T. T. A. Li, and J. E. Cotter, Appl. Phys. Lett. 88, 263514 (2006).

${ }^{5}$ M. Vetter, R. Ferre, I. Martin, P. Ortega, R. Alcubilla, R. Petres, J. Libal, and R. Kopecek, Proceedings of the Fourth WCPEC, Hawaii (IEEE, Piscataway, NJ, 2006), p. 1271.

${ }^{6}$ G. Agostinelli, A. Delabie, P. Vitanov, Z. Alexieva, H. F. W. Dekkers, S. De Wolf, and G. Beaucarne, Sol. Energy Mater. Sol. Cells 90, 3438 (2006).

${ }^{7}$ B. Hoex, S. B. S. Heil, E. Langereis, M. C. M. van de Sanden, and W. M. M. Kessels, Appl. Phys. Lett. 89, 042112 (2006).

${ }^{8}$ M. J. Kerr, Ph.D. thesis, Austrialian National University, 2002.

${ }^{9}$ J. L. Hemmen, S. B. S. Heil, J. Klootwijk, F. Roozeboom, C. J. Hodson, M. C. M. van de Sanden, and W. M. M. Kessels, J. Electrochem. Soc. 154, G165 (2007).

${ }^{10}$ R. A. Sinton and A. Cuevas, Appl. Phys. Lett. 69, 2510 (1996).

${ }^{11}$ D. E. Kane and R. M. Swanson, Proceedings of the 18th IEEE Photovoltaic Specialists Conference, Las Vegas (IEEE, Piscataway, NJ, 1985), p. 578.

${ }^{12}$ M. J. Kerr and A. Cuevas, J. Appl. Phys. 91, 2473 (2002).

${ }^{13}$ P. P. Altermatt, A. Schenk, F. Geelhaar, and G. Heiser, J. Appl. Phys. 93, 1598 (2003).

${ }^{14}$ A. Cuevas and R. A. Sinton, Prog. Photovoltaics 5, 79 (1997).

${ }^{15}$ M. J. Kerr, J. Schmidt, A. Cuevas, and J. H. Bultman, J. Appl. Phys. 89, 3821 (2001).

${ }^{16}$ M. A. Green, Solar Cells: Operating Principles, Technology and System Applications (Prentice-Hall, Upper Saddle River, NJ, 1982),

${ }^{17}$ SENTAURUS, Mountain View, CA (www.synopsys.com/products/ tcad/tcad.html). 